\author{
OLEG MALTSEV, \\ Memory Institute (Odessa, Ukraine) \\ e-mail:kbsp613@gmail.com,ORCID 0000-0002-8589-6541
}

\title{
PREDISPOSITION AND SKILL DIALECTICS IN THE HUMAN PROFESSIONAL ACTIVITY: PHILOSOPHICAL COMPREHENSION
}

\begin{abstract}
In our philosophical exploration we shall originally analyze dialectical contradictions of predispositions and skills as a source of memory phenomenon development; the patterns leading to the human professional activity evolution, as well as the identification of obstacles and barriers. The area of human orientation in the world of changing opportunities under the influence of the information society formation, hyper-reality and Smart Society in the cognitive innovation perspective, which is defined in the twenty-first century in the novelties of the labor market, new professions, in the processes of technological development, digitization, and transition to the virtual world of communication networks and the Internet, is justified. Moreover, studies of the memory environment reveal a search for "a certain space of inclination," as well as "corresponding features of each block" of the memory environment, determining the patterns of individual professional selection and prospects of a figure, as the subject not only of professional activity in particular, but of life in general. The correlation of the activity approach developments within the development of the subject's life as well as the model of predisposition realization by $M$. Achtnich mentioned as holistic and optimal one, maintained by the specific-historical conditions of the figure, have mostly determined the key problem, which this article is devoted to. The purpose of this scientific exploration is the philosophical understanding of predisposition and skill dialectic in human professional activity (on the example of models by Martin Achtnich and Gregory Popov). The achievements of the theoretical model of Gregory Popov represent the significant results of the solution of the issue, to which P. Drucker reached himself in his formulation of "Smart Approach." It is the aforementioned concept that stands now decisive for the prospects of a "smart society" dispute in various activity spheres. Furthermore, the following disposition considers the praxeological perspective of knowledge of the patterns of the "inclination-skills" contradiction resolving application based on the models of G. Popov and P. Druker.
\end{abstract}

Keywords: memory phenomenology; memory environment; predisposition; skill; choice of profession; smart approach.

\section{Introduction}

Globalizations, international migration of people, changes in the labor market around the world and determine the relevance of philosophical thinking of "economic person" or "working person." Whereas G. Skovoroda's "Srodnya Pratsa" has always remained relevant in the Ukrainian philosophical definition, in the globalizing world there is an experiment pretending to replace the professional vocation with a set of competencies; this process is embodied in the system of education and unification of industrial society, which is still preserved as chaotic and synergistic processes, depending on the points of polyfurcations of company managers in their HR activity, selection, financing the non-formal schooling. Philosophical reasoning, in our opinion, of a flawed approach to what the famous philosopher A. Zinoviev (Kantor, 2009) declared a modular person (with an "ant-man" analogy in the meaning of mechanistic, not genuine unification of people, requires comprehension of the predisposition and its realization relationship, what is defined in a stable realization form as a skill).

The research subject gets updated with 1) the chan- ges, connected with a de-actualization of a number of industrial society professions, on the contrary, 2) the new professions declaration of information civilization and the cognitive and innovative prospect of society development, which received already the "smart" prefix, i.e. smart skills, smart professions (intelligent, cognitive professions), smart competences (competences of cognitive professions. In connection with the description presented, it is approved in society to form a cognitive class, as an engine of social changes, out of which the progressive transformations are expected (Silberman, 2000).

In the problematic field of our article, the scientific task implies to acknowledge the existence of universals of a person's predisposition to a profession in its dialectical unity and struggle against skills, carrying out professional activities.

\section{Materials and Methodology}

The theoretical background of our work is based on research of industrial and information society, the development of hyper-reality, the cognitive and innovative perspective of social development. 
Amongst the theorists of industrial society the following works are represented: the works of the critical approach to social destruction of the developed industrial society of the Frankfurt school, which is sometimes provisionally called Freud-Marxism, regarding the influences of the ideas of Marxism and the theory of psychoanalysis of $Z$. Freud, as well as the original socially-oriented conceptualization of Erich Fromm (Fromm, 2010). These are, first of all, the works of M. Horkheimer, T. Adorno principally declared in their collective significant work "Dialectic of Enlightenment" (Horkheimer, Adorno, 1997), F. Pollok (2018) and G. Marcuse (1994). Herbert Marcuse defined the specifics of social destruction, including ones in professional activity, in the following works: "One-dimensional man. Research on the Ideology of a Developed Industrial Society" and "One-Dimensional Thinking".

Next, a significant contribution to the research theory of formation as well as post-industrial perspective was delivered in the works of the younger generation, so-called Frankfurt School - the "younger generation" of Frankfurt, i.e.: the existentialist version of Alfred Schmidt (Schmidt, 1981), and the founder of the theory of communicative action Jürgen Habermas (Soboleva, 2002).

Recent thinking about the legacy of Frankfurt school is applied in the works of L. Bronzin (Critical sociology of Frankfurt school, 2007), G. Borisova (2007), etc.

The works of R. Aron, D. Bell, E. Giddens, Z. Bzezinski, I. Wallerstein, M. Castels, Y. Lotman, N. Luman, W. Maturan, J. Neusbit, O. Toffler, F. Fukuyama regarding the Information Society, determined the evolution of the developed information society into the post-information phase of the smart society (Bell, 1976). In Ukrainian philosophy it is worth noting the works of V. Voronkova School (Voronkova, Kyvliuk, Andriukayte, 2018).

An essential conceptual outline of our article lies in the definition of the proportion not only of the "extra repression" of social institutions, as well as L. Szondi's "imposed fate" definition, introduced as a condition of professional development of man, but also of the dialectical contradiction "predisposition - skill," as a pattern revealed by M. Achtnich (1979).

Moreover, the activity approach of G. Popov (1951), initiating as a basis the resolution of the contradiction predisposition-skill in removing the influence of the destruction of society and unconscious ancestral scenario of L. Szondi's "imposed destiny", is applied, as well (Szondi, 1956).

Scientific Originality. In our scientific exploration, we shall consider a logical model, guiding one closer to the integrated comprehension of barriers and obstacles set existing in the memory environment, "refracting" human predispositions and turning them into skills, for the first time. The area of human orientation in the world of changing opportunities, as well as in solving the "predispositionskill" conflict at the of new professions formation stage in a smart society of cognitive and innovation perspective, is defined with the twenty-first-century criteria of technological development, digitization and transition to a virtual world of communication networks and the Internet, is justified.

The purpose of this scientific exploration is the philosophical understanding of predisposition and skill dialectic in human professional activity (on the example of models by Martin Achtnich and Gregory Popov).

Results and Discussion

Through the transition to the latest era, in our case, the one defined by the globalized economy and the struggle of simulation hyper-reality with the attempt to form a reasonable society, conceived in the definition of "smart society" or "cognitive and innovation perspective" (system, society, etc.), as well as the transition to a new era, there is always a conflict between people who have lost reflection and self-consciousness and those who defend reason as a common human value. Sometimes, this backing takes the form of mythologization and politicization, which assists the loss of ability to think critically.

For the first time, the attention to this problem was paid in Frankfurt school.

Education is defined by M. Horkheimer and T. Adorno as the "myth of the twentieth century" (Horkheimer, Adorno, 1997). It is a myth about the mind that conquers nature; the mind, capable to create a just society: a beautiful idea that leads the society to realize (most often, artifice) that not the people themselves rule in history, but the necessity and blind destiny. "Education is more than enlightenment, it is nature perceived in its isolation." This is due primarily to the fact that the West rationality is perceived as a technical capacity of practicing violence against nature. However, if the case was limited to the "violence against nature" paradigm, that outcome would not be so sad; everything gets worse as the process of "materialization" penetrates the culture and implements its unification and standardization. As a result, the person changes: not only his ability to reflect, to independent intellectual thinking and creative activity declines, but also the ability to "grab" and reproduce cultural stereotypes and clichés develops very quickly (Critical sociology of Frankfurt school, 2007).

That is the reason, throughout such periods people tend to return to the recognition of the meaning of "fate", "destiny", "predisposition".

At the same time, the key factor is always representing an attempt to suppress a human desire to answer these questions on their own by violence or pressure, not because it imposes official ideology or the mainstream media. This factor converts decisive in the simplification of man, and often the destruction of society. As G. Marcuse wrote, "It is not about the very fact of need, but about how it is distributed among the members of society, i.e. that in the interests of domination, in the interests of the privileged group, additional suppression is placed on the shoulders of the rest" - so-called "extra repression" (Yudin, 1995).

That is the reason the formation of a cognitive and innovative perspective as the reasonable society development requires a request to the opposite - to the collective unconscious, to the fact that at the level of mass the individual psychology prevents a person from maturing as a subject of life, the captain of his destiny, if paraphrasing the words of W. Churchill.

A significant contribution to the display of the problem of human dependence on imposed destiny and professional choice was made in the 40-50 years of the 20th century by the Hungarian psychologist and psychiatrist Lipot Szondi, who first acquainted the concept of "imposed destiny".

According to L. Szondi's conceptualization of "imposed destiny" phenomenon, introduced in his work "I-Analysis," the teaching of fate holds the view that in each destiny the person must distinguish between the part of "imposition" and part of "freedom" in his life (Szondi, 1956). These 2 parts of Fate (according to L. Szondi) are related to one another in the following way: "Bricks and plans for building one's destiny are delivered by his ancestors. Any ancestor distributes his special requirement for life, his special form of life, acting meanwhile for descendants as a "specimen or image".

Each "ancestor" results in the human ancestral un- 
conscious as one special possibility of the future. We possess and bear in the inner plan of our destiny (which we call the "ancestral unconscious") multiple different ancestors, and thus many, most often extreme contrast possibilities of fate. Individually ancestor figure in the ancestral unconscious tends to act as a "specimen" for the fate of the descendant. This is the imposition of the choice of ancestors in love, friendship, profession, disease, and death (Achtnich, 1979; Szondi, 1956).

It is precisely this part of the imposed and conditioned part of the fate that we call the imposed destiny". The instance, which of these family-laid different planned possibilities of fate just chooses for itself the personal fate, while everything else denies, is "I." "It is the deliberately chosen part of destiny that we call the fate of choice" (L. Szondi "I-analysis").

Fate most often reflects the repeated unconscious strategies of life (if we use the concept of $\mathrm{K}$. Abulkhanova (Abulkhanova, 1991)), which oppose activities that are helpful, efficient, rational.

Thus, Martin Achtnich pretends to be the follower of the traditions of the teaching of fate by Lipot Szondi, his specific ideological inspiration. However, the core of Achtnich's research is not focused on the study of "destiny" phenomenon in general, but rests straight on the identification of key features of professional fate formation, especially in terms of studying the principles of unconscious human choice for future occupation (Achtnich, 1979).

The Hungarian-Swiss scientist, psychiatrist, and fatologist Lipot Szondi studied the unknown inter-human function of the unconscious and introduced the "genotropismus" name for it. Genotropismus refers to the process of the fact, identical or related hereditary factors in the ancestral "fund" (that is, in the ancestral unconscious of two people) attract these people to each other, which ties or brings them together. Therefore, genotropismus is one of the most significant functions of the ancestral unconscious. This "genotropismus action" of latent ancestral predispositions proceeds in the unconscious mental area, as well (Szondi, 1956).

L. Szondi also explained that latent (hidden) hereditary predispositions may control a person's choice of actions in an unconscious way. Genotropically activated hereditary factors are the very active elements of the ancestral heritage that, through choice, cause the future fate of a person (Szondi, 1956).

The ancestral unconscious "exhibits" its dynamic aspirations in "genotropismus" form by the action of choice. The ancestral unconscious expresses its demands in the "language of choice." By Szondi the elective categories may vary in:

- Selection of the object of love;

- Choice of the object of friendship and partnership;

- Choice of profession and occupation;

- Choice of disease;

- Determining the representation of death.

Martin Achtnich, having studied and described the structure and manifestations of unconscious professional choice, also emphasized three directions: 1) a key motor factor creating for an individual sense in its usefulness and the possibility of its best realization (e.g., "building anything is useful", "I think I could construct something new and wonderful"; 2) conditions of professional activity (individual has an idea where, under what circumstances he would like to do or accomplish something); 3) the action itself - its image, method and tool (for example, "to build not only means to lay some bricks, but also to do it beautifully, according to the plans of the building." Con- sequently, the next step in our analysis involves defining the disposition of the model and then relating it to the activity theory.

Unspecified changes in the structure of knowledge and skills give increase to considerable resistance in the person, still, he is forced to acquire additional knowledge since in case of other issues, he is not familiar with, and this knowledge may not be enough.

Achtnich's credit is that he, on the one hand, classified and explained all the motor skills of the ancestral concept in the form of motor reactions. On the other hand, he provided a list of motor reactions with a specific conclusion about the perspective: finishing with the "profession diagnosis" (the characteristic of a particular profession rendered from motor skills set).

One of the significant results of Achtnich's research is in the following: he managed to verify the occupation peculiarities of women and men in the differentiation of specialties noted by gender, resulting in the scientific test. Hence, he revealed a common and special "male world" as well as the world of professional activity in the eyes of a woman as a subject of her personal life. Furthermore, Achtnich allowed recognizing the peculiarities of behavior of a woman and a man through the "spectacles" of motor reactions, and in fact, by analyzing the movements and characteristic of them (Achtnich, 1979). The following model of human memory operation, presented below, allowed him to solve this complex task:

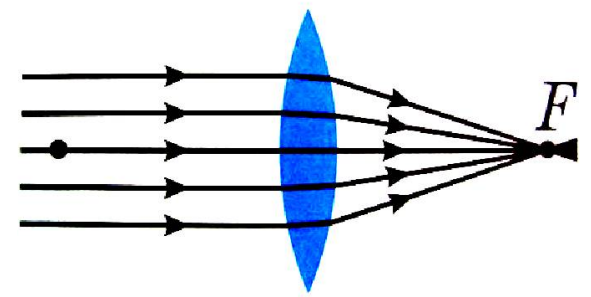

Figure 1. Model of realization of human motor skill predisposition in memory environment

Therefore we are to analyze the model of conversion of predisposition into the motor skill of a man. We will pay attention to the second part of Figure 1. It represents a beam of light passing through a "lens". This is what a logical model looks like; the key to learning the language of the Achtnich test. The beam of light is the key stimulus of man and his "primary factor." Furthermore, the "lens" (or "eyeglass") is that light refracts, therefore twisting the stimulus. The lens allows the light passing. According to the language of the Achtnich test the lens is called "secondary factor".

According to the figuratively described logical model, the "light" is related to the category "predisposition," while the "lens" represents 1) conditions or circumstances, and 2) education - solely that formed the lens (through which the light goes). Now in this analogy M. Achtnich considers the dialectical relationship of objective (genetically and phenotypically conditioned) - predisposition, and subjective (objective in social) - in his training. Later aforementioned conflict, confrontation, and unity of these opposites are specified in the "predisposition-skill" relationship. Fairly important in his description was the reflection of measure loss as the qualitative issue of the matter.

The following explanation should be reinforced with an example: let's pretend a man can shoot; we analyze this motor skill through the lens of A) war circumstances and $B$ ) peaceful non-military time. In the end while refracting 
his skill (at the end of the realization of the motor skill), man acquires different statuses: A) war circumstances produce a "hero"; B) peaceful non-military time - a criminal. There is stimulus (primary factor); there are circumstances - through WHAT the main stimulus (secondary factor) will be refracted. As a result a piece of data on the Achtnich test represents a "key inducements" and a descriptive body of "circumstances" that might get explored in a comprehensive way (Achtnich, 1979).

It should be noted that the key motivation is unconscious. Both factors, like two interconnected components, remain unconscious.

Subsequently, Martin Achtnich repeatedly studied the study of the very "refractive lens" formed by the memory environment (Achtnich, 1971). Nevertheless, a task to name in a complex its components, components, and structure were never complete by Achtnich himself. The scholar finished with having stopped on two basic categories 1) education of the person and a 2) circumstances dictated by life. In fact, these two criteria for lens formation are parameters are defined by a memory block such as the ancestral unconscious reasoning, repeatedly described by L. Szondi and verified by his writings and projective tool "Stimulus Test" or "Choice Test." M. Achtnich himself, suspecting there are other systems affecting the system of professional predispositions transformation, was powerless to bring them out by empirical means (which, in particular, defined subsequent scientific research in the field of memory study and perception of its processes and mechanisms) (Achtnich, 1971).

Yet Martin Achtnich managed to expand the concept of "professional requirements": "According to the test and the respondents' answers, we recognize not only the abilities (intelligence, talents, hand agility, etc.) that a specialist must possess, but also the needs that must correspond to the structure of predisposition of the relevant profession. Only when the person shares both the necessary skills and predisposition, can he be assumed to remain faithful to the profession and to be a healthy, successful, professional character" (Achtnich, 1979; Achtnich, 1971).

M. Achtnich thus allows us to derive the assurance of a person's professional destiny; to produce a prediction for his effective future paradigm in a form of the description of what could be achieved respondent's life, based on his birth predisposition, as well as interacting in complex with multiple factors of the unconscious. In fact, his tool of professional orientation allows us to predict not one profession, which is to be realized qualitatively by a person, but overall 4 (four) before-mentioned professions. One of the discoveries of M. Achtnich acts as a four-stroke system of professional realization (Achtnich, 1971).

Achtnich's professional orientation test, in particular, shows the way the person is capable to attain:

1) "Instant success";

2) A profession in which he realizes himself as an effective leader;

3) Alternative profession, allowing one to expand geography and potential of his business already functioning (in the firm or company form, or any other coordinate system);

4) "Non-instant triumph" (a profession field in which man will act as No. 1 expert).

In fact, the first and fourth profession results (i.e. the primary transient success and "eternal triumph") as the two categories constitute some two extreme points of career and professional transformation, moreover, "the middle" indicates intermediate steps of the professional fate of the individual. The study of this issue sets the foundations for the natural resolution of the predispositionskill contradiction, which is a universal, repeated at various stages of individual and societal development. This pattern allows us to explore the changes in the developed information society further, as well as the attraction to hyperreality, the simulation of objective life, or the preservation of "reason" issues as objectivity in the measurement of the future society (Achtnich, 1971).

A certain achievement of Martin Achtnich is not only the assumed models detailing the profession or activity of man, but also the description of the causes of conflict in this issue, which always arises if the person is engaged in non-friendly business. The follower of Szondi produced a lot of scientific and practical work, helping one to eventually get closer to solving the problem of predicting the professional fate of a person.

However, based on the model of M. Achtnich, which we will provisionally designate as "Light-Lens," a number of questions remain non-revealed; in particular, the following one: what determines the quality of the prism in the human memory environment and how this prism refracts the message generated by memory mechanisms (Achtnich, 1979).

It should be noted that to this pattern of resolution of dialectical contradiction predisposition-skill, the academician G. Popov arrived in justifying the complex heuristic model, presented in his work "Phenomenology of Memory", independently of Achtnich's works (Popov, 1951).

In fact, M. Achtnich concluded empirically, a person may beget 4 professional acts allowing him to achieve "triumph", the highest accomplishment in his professional life and practice. However, M. Achtnich deduced these patterns observationally, further classifying them, relating multiple test results (for 25 years of professional activity he was testing together with colleagues more than 14.000 people; 16 years earlier, he contributed to develop the test itself and its validation). Based on the model recommended by academician G. Popov, we observe this "4 professional acts system" really exists, as it derives from the structure of the human memory environment.

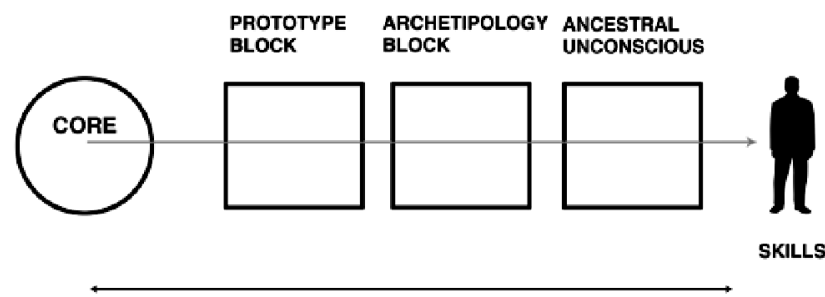

MEMORY ENVIRONMENT

Figure 2. Memory model by G. Popov

Nevertheless, personal predisposition is "refracted" not only through the "prism" or "lens" of ancestral heritage (M. Achtnich suspected that, describing to his students the prospects of further research), but transfers through diverse configurations generated by four blocks of memory: its core, prototype block, archetipology block and block of the ancestral unconscious; only later the trainings are "fixing" the "result" in his consciousness, finally turning into a motor skill.

M. Achtnich did not examine how the interaction of memory potential takes place refracting predisposition through individual prisms of the prototypical block, the archetipology block, etc. Additionally, the author of the professional orientation test laid the foundations for further research in the field of the change of professions system 
study. In other words, crucial questions remain uncovered: A) what happens to professions that die? B) How to orient and choose a new, relevant profession, which is not described in the test apparatus directly? C) How does the emergence of new professions relate to the human memory environment and its motor features?; D) can we give an answer about the professions of the future - how to predict them, verify them?

The fact is that the apprehension of the memory environment features and the search for an "exhaustive list of predispositions," as well as an "exhaustive list of features each memory environment unit" is achievable from a scientific point of view, however, that usually takes years of research while working with one person. From a practical viewpoint, this is unacceptable, because in modern circumstances such recommendations are required, which allow to predict professional activity in just a few hours, plus in the future to allow a person to learn to navigate independently in conditions of changes in the environment of his life and activity.

Popov's tasks largely echo the original formulation of P. Drucker's "smart approach". The term "SMART-society" was introduced by P. Drucker in early 1954, the first letters of the notion meant: S - Self-Directed; M - Motivated; A Adaptive; R - Resource-enriched; T - Technology. SMART criteria are to be met by the objective: 1) specific (what needs to be achieved) 2) measurable - assessable (the result is to be estimated) 3) attainable - achieved (by which it is possible to achieve the objective); 4) relevant - up-todate (determination of the truth of the goal) 5 ) time-bounded - date-specific (determination of the time interval after which the goal is to be achieved). Correct setting of goals determines their specificity, measurability, attainability, significance, and relevance to a specific term, indicating the first letters of a given term (Maksimeniuk, 2016).

If at that time P. Drucker's approach was pointed exclusively at training managers, however, presently there is a reflection of the smart approach to all areas of activity (by a certain rate of change, rapid circulation of information and conditions of uncertainty).

As well as mentioned, we are to note another most prominent pattern, defined by the contradiction of predisposition-skill, which is the essence and manifestations of the profession itself.

Thus, M. Achtnich predicting changes in the structure of the professional field, left followers and the next generation of scientists with the following conclusions. The very concept of "profession" he considered as a composite construct formed by several elements (Achtnich, 1971):

1) The motor skill itself - its predisposition in the unconscious version of memory mechanisms actuation;

2) Environment in which this profession is realized;

3) Workplace, as well as the way of work organization on the spot

4) Profession tools.

The leading relationship in this scheme is the "predisposition - skill" relationship, as it is the main object of the profession, its "spine" or "rod". If there is no skill, the person will not be successful in the selected position (Achtnich, 1979; Achtnich, 1971).

Subsequently, when predicting subsequent professions, taking into account the mandatory conditions of modern transition to the world of the Internet and social networks, based on the above-mentioned configuration, we get the following ranking on changing and unchanged components.

The option a person does not change (or changes very slowly) is the content of the memory environment, is his predisposition. Moreover, in forecasting and professional orientation, we A) cannot influence the predisposition system; B) should pay direct attention to what a person will be able to realize at the maximum speed and in the best possible way; C) are primarily interested in predisposition, as it is the basis of the future skill, and therefore the "key" to the success in the professional field.

However, the other three components must necessarily be taken into account at solving contemporary problems. In particular meanwhile moving into the world of "hyperreality" and digitization, based on the perspective of the profession, we recognize changes in the environment. Therefore, while forming a professional package of recommendations and subsequent methodological developments, we should also take into account 1 ) the system of environmental management in which this skill will be implemented; 2) a changing set of modern tools for the realization of the profession; 3 ) method of human selforganization and self-documentation. Simultaneously, if a key role in the industrial world was played by the "predisposition-skill" system and it was possible to accomplish oneself in concrete environments of the physical world (the plants, factories, institutes, and so forth); today the task becomes complicated repeatedly. It is not enough to solve the issue of identifying professional predispositions as this the first stage of prediction-making. Promptly it is necessary to invent the system №2, without that one the realization of predisposition is impossible - namely, the system of skill fulfillment in the 21-century environment, in the environment of the Internet, virtual worlds, and the desire to replace physical processes with electronic ones.

Smart is a property of an object that characterizes the integration in a given object of elements that are not previously combined, carried out through the use of the Internet. That indicates this process is available and not taking this it into account means simply turning a blind eye to the apparent reality. For example, Smart-TV, Smart-Home, Smart-Phone Smart-technology, "smart" generally leads to the expansion of labor mobility in education, public service as well as various other areas of employment, especially among young people, meaning this concept is central to the consideration of social changes (Karmanov, 2014).

The third stage, therefore, will require the development of new tools of professional implementation (video camera, computer, smartphone), and these tools shall be learned to use even by experts not directly involved in activities on the Internet (doctors, lawyers, builders, etc.). The 21-century environment dictates these rules, changing the life of man, and consequently the order of self-realization.

Methodological developments of such programs of training and education will become extremely promising, which necessarily take into account earlier mentioned parameters, allowing to solve the task of expert formation comprehensively, answering not only the question "What profession is one to choose?" but "How to implement it in modern requirements of expanding hyper-reality".

Hence, the team of authors under the leadership of Professor V. Voronkova writes that "In the context of universal human values development such as geosciences of planetary scale, the concept of "Staffing of personnel" is a trajectory that cannot be isolated from the world, as it is extremely developing. As a central topic of public theory, "staffing" is a term referring to the representation of staff on certain terms: staff leasing - "rental" of staff, temporary staffing - delivery of temporary staff for a short period, "outstaffing" - withdrawal of staff abroad, which requires reflection and corresponding actions (Voronkova, Kivlyuk, Andryukajtene, 2018). 
Staffing essentially defines globalized systems of production speed mode with professional activities of organizations. We find answers to these challenges in the results of research activities of G. Popov.

For a number of the above-described reasons in searching the aspect of unconscious choice carried out by man, including the professional terms Gregory Popov developed the following approach from advancing the methodology of human education. Thus, he did not recommend to consider a "profession" option as a choice matter or a "case to which relatives were engaged"; not as "an occupation to the liking" and even "not an option helping one to survive." The academician termed these categories unpredictable ones as they only created unnecessary obstacles in solving the poorly structured task of professional orientation (Popov, 1951). The innovation of G. Popov's practical recommendations is precisely to show a person how to stop choosing anything unconsciously, consequently condemning his career to dependence on the game of probabilities.

Alternatively, it is recommended to choose diverse categories: 1) tactics, 2) philosophy as a system of applied knowledge (in the modern meaning of applied philosophy), 3) management and 4) approach to life conditions management. For instance, everyone may learn to create the right environment helping him to solve the problem that is most likely pushing to the fulfillment of the tactical intent of managing these systems and circumstances. That defines and deploys in practice the right choice of ethical and moral attitudes and, consequently, effective management, allowing the person to build his professional fate himself, without choosing the paths offered to him by the heritage of ancestors claiming to expose their existences (Popov, 1951).

The logic of academician G. Popov aims precisely to stop choosing anything unconsciously and "swim along the flow of life." Preferably, it is necessary to choose tactics, philosophy (system of ethical-moral values of man), management, and ability to manage requirements. Otherwise, anything happening next is uncontrollable and filled with life obstacles. Moreover, effective management implements the requirements that are most likely to lead to the realization of tactical intent. The right choice of philosophy also generates management directed at solving life problems, and the choice in favor of effective knowledge allows us to think through competent tactics of actions, helping to cope with any circumstances (Popov, 1951). Furthermore, if a person chooses these four components rather than "following the flow of life" or an unconscious "ancestor requirement," then the unconscious processes and memory mechanism system start functioning under control of the individual. Through that, the so-called "axis force addition principle" initiates, that is: the refractor or "lens" of each memory unit repeatedly amplifies the "light" generated by the memory core. In such a case there are opportunities for effective development and realization of the person's potential, which is in every way facilitating his professional climbing to Pedestal.

\section{Conclusions}

Based on the purpose of the presented scientific exploration, which is to understand philosophically the predisposition and skill dialectic in human professional activity, a comparative analysis of the models of Martin Achtnich and Gregory Popov was presented.

First, the logical model of M. Achtnich is defined; describing and demonstrating the ways a person's predisposition ("information" about which is stored in his memory) is converted into a skill. As well as these, the

ISSN 1728-9343 (Print)

ISSN 2411-3093 (Online) problem of system prediction of the predispositions order implementation method in the way of transforming a predisposition into actual and effective skills is defined.

Secondly, the method of comprehending the "system of achieving effective professional realization in life," described by M. Achtnich in the form of four acts, is critically analyzed. Thus, the scholar provided a classification of the four professional milestones that occur in the life of each individual, however, he did not have enough time to describe the parameters or structure meeting an answer to the question "How to manageably achieve these milestones?" but he demonstrated that this is possible, and that this "achievement of triumph" is available to study.

Thirdly, based on the previously described assumption, the activity approach of G. Popov was also considered, who set into the basis the resolution of the contradiction "predisposition-skill" in removing the influence of the destruction of society and the unconscious ancestral scenario of the "imposed fate" of L. Szondi. This has made it possible to develop a set of tactical recommendations regarding the experience and resolution of this contradiction in life and professional practice.

The fourth conclusion states the comparative analysis revealed, Popov's tasks largely echo the original formulation of P. Drucker's smart approach, whose paradigm is now being applied to reflect on the smart approach to any areas of activity, defined by the speed of environmental change, the rapid circulation of information, and the circumstances of uncertainty. The recommendations of G.Popov and the concept of P. Drucker do not conflict, mutually complementing each other.

The fifth point is the most significant pattern, defined by the "predisposition-skill" contradiction, which was noted as the essence and manifestations of the actual "profession," the key description of which was conducted by Martin Achtnich. Nevertheless, the dynamics of contemporary realities (digitization, a transition of a number of professions into the "virtual world," generation of unlike professional requests caused by social networks and world integration, which are increasing role of individual positioning on the Internet, etc.) allows to detect and predict the formation of cognitive class, from which as an engine of social changes progressive transformations are expected.

Methodological developments of such programs of training and education will become extremely promising, which necessarily take into account earlier mentioned parameters, allowing to solve the task of expert formation comprehensively, answering not only the question "What profession is one to choose?" but "How to implement it in modern requirements of expanding hyper-reality".

Consequently, the most significant prospect of further research lies in praxeology, in the practical development of appropriate education and training programs for experts of different specialties, taking into account the requirements of the 21-century environment. Moreover, although the approach in each individual case in the education process is usually individual, from the pedagogical and methodological viewpoint the presented models of resolution of the "predisposition-skill" contradiction and recommendations for their applying are current and promising contemporary scientific tasks.

Special attention should also be paid to the achieving professional triumph system as an assuring field of further research: both from the philosophical point of view of the mechanisms, tactics of self-improvement, and realization of the potential of the individual studies, and from the viewpoint of the methodologies yet not developed.

SKHID No. 3 (167) May-June 2020 


\section{REFERENCES}

Abulhanova-Slavskaya, K. A. (1991). Strategiya zhizni. Moscow: Mysl. (In Russian)

Achtnich, M. (1979). BBT - Berufsbilder-Test. Projektives Verfahren zur Abklärung der Berufsneigung. Bern: Hans Huber. (In German)

Achtnich, M. (1971). Schicksalsanalytisch Orientierte Berufsberatung Anhand des Berufsbilder-Wahltestes. Ein Beitrag zur Psychologie der Berufswahl, des Berufswechsels und der Berufsprognose. Bericht über das 5 . Kolloquium der Internat. Forschungsgemeinschaft für Schicksalspsychologie. Bern: Hans Huber. (In German)

Bell, D. (1976). The Coming of Post-Industrial Society. A Venture in Social Forecasting. N. Y.: Penguin \& Co.

Borisova, G. (2007). Sotsialnaya destruktsiya kak universalnyy fenomen zhizni obshchestva (pozitsiya frankfurtskoy shkoly). Bulletin of the Nizhny Novgorod University. N. I. Lobachevsky. Series: Social Sciences. Retrieved from https://cyberleninka.ru/article/n/sotsialnaya-destruktsiya-kak- universalnyyfenomen-zhizni-obschestva-pozitsiya-frankfurtskoy-shkoly2 (In Russian)

Fromm, E. (2010). Po tu storonu poraboshchayushchikh nas illyuziy. Kak ya stolknulsya s Marksom i Freydom [Beyond the Chains of Illusion: My Encounter with Marx and Freud]. Moscow: AST. (In Russian)

Horkheimer, M. and Adorno, T. (1997). Dialektika Prosveshcheniya. Filosofskiye fragmenty. Moscow-St.Petersburg: Medium, Yuventa. (In Russian)

Kantor, K. M. (2009). Logicheskaya sotsiologiya Aleksandra Zinovieva kak sotsialnaya filosofiya. In: Aleksandr Aleksandrovich Zinoviev. Moscow: ROSSPEN. (In Russian)

Karmanov, A. M. (2014). Smart kak novaya stupen razvitiya postinformatsionnogo obshchestva. Ekonomika, statistika $i$ informatika, 5: 38-41. (In Russian)

Kriticheskaya sotsiologiya Frankfurtskoy shkoly (2007). Vestnik
Rossiyskogo universiteta druzhby narodov. Seriya: Sotsiologiya, 3: 52-67. Retrieved from https://cyberleninka.ru/article/ n/kriticheskaya-sotsiologiya-frankfurtskoy-shkoly (In Russian)

Maksimeniuk, M. Y. \& Nikitenko, V. O. (2016). Informatsiynokomunikatyvne suspilstvo yak riznovyd skladnoyi sotsialnoyi systemy i vzayemodiyi. Humanitarnyy visnyk Zaporizkoyi derzhavnoyi inzhenernoyi akademiyi, 66: 266-278. (In Ukrainian)

Marcuse, G. (1994). Odnomernyy chelovek [One-dimensional person]. Moscow: Refl-book. (In Russian)

Pollock, F. (2018). Zur Geldtheorie von Karl Marx. Inauguraldissertation. Wirtschafts- und Sozialwissenschaftliche Fakultät der Universität Frankfurt am Main [Masch.] 1923. Nachdruck: Freiburg: Wien, 2018. S. 23-127. (In German)

Popov, G. S. (1951). Fenomenologiya pamyati: osnovnyye metodologicheskiye podkhody $\mathrm{k}$ issledovaniyu pamyati cheloveka. [Rukopis]. Manuscript. Archive "NII Pamyati" - Arhiv NIIP (NII Pamyati) Fond 3 (Fond "Nasledie akademika G. Popova", Vena 1940). File 2, List 1. Fp.1-6. S. 41-50.

Schmidt, A. (1981). Kritische Theorie, Humanismus, Aufklärung. Philosophische Arbeiten. Stuttgart: Reclam. (In German)

Silberman, M. and Hansburg, F. (Contributor) (2000). People Smart: Developing Your Interpersonal Intelligence. Oakland, CA: Berrett-Koehler Publishers.

Soboleva, M. (2002). K kontseptsii filosofii yazyka Yurgena Khabermasa. Logos. (In Russian)

Szondi, L. (1956). Ich-Analyse. Die Grundlage zur Vereinigung der Tiefenpsychologie. Teil 1. Bern: Hans Huber. (In German)

Voronkova, V. \& Kivlyuk, O. \& Andryukajtene, R. (2018). Antropolohichni vymiry smart-suspilstva: teoretyko-kontseptualnyy dosvid. Humanitarian bulletin of ZGIA. 73: 25-40. Retrieved from http://www.zgia.zp.ua/gazeta/gvzdia_73_25.pdf (In Ukrainian)

Yudin, A. (1995). Paradoksy Velikogo Otkaza. In: Markuze G. Eros i tsivilizatsiya. Filosofskoye issledovaniye ucheniya Freyda. Kyiv, 275 p. (In Russian)

Олег Мальцев,

Інститут Пам'яті (м. Одеса, Украӥна)

e-mail:kbsp613@gmail.com,ORCID0000-0002-8589-6541

\section{ФІЛОСОФСЬКЕ ОСМИСЛЕННЯ ДІАЛЕКТИКИ СХИЛЬНОСТІ І НАВИЧКИ В ПРОФЕСІЙНІЙ ДІЯЛЬНОСТІ ЛЮДИНИ}

У статті аналізується протиріччя схильностей та навичок як джерело розвитку феномену пам'яті, та закономірності, які обумовлюють розвиток професійної діяльності людини. Обґрунтовано напрямок орієнтації людини у світі, тих можливостей, що змінюються під впливом розвитку інформаційного суспільства, гіперреальності та смарт-суспільства в когнітивно інноваційній перспективі, що проявляється у XXI столітті у змінах ринку праці, появі нових професій, у стрімкому технологічному розвитку, діджиталізації та переходу у віртуальний світ комунікаційних мереж та Інтернету. Дослідження середовища пам'яті відображає і пошук "визначеного простору нахилів," так само як і "відповідних особливостей кожного блоку" середовища пам'яті, що визначає закономірності професійного відбору та перспективи зростання діяча, як суб'єкта не тільки діяльності зокрема, а й життя в цілому. Співвіднесення розробок діяльнісного підходу в розробці суб'єкта життя та моделі реалізації схильності М. Ахтніха, як цілісного й оптимального в конкретно-історичних умовах діяча, і визначило ключову невирішену проблему, якій присвячена дана стаття. Мета розвідки полягає в філософському осмисленні діалектики схильності і навику у професійній діяльності людини (на прикладі моделей Мартіна Ахтніха і Григорія Попова). Здобутки теоретичної моделі Григорія Попова репрезентують суттєві результати вирішення цього питання, до якого значно пізніше самостійно дійшов П. Друкер у своєму формулюванні "смартпідходу". Саме цей концепт є визначальним для обговорення перспектив "розумного суспільства" у різних срерах діяльності. Розглядається праксеологічна перспектива застосування знання закономірностей вирішення протиріччя "схильності - навички" на основі моделіей Г. Попова та П. Друкера.

Ключові слова: феноменологія пам'яті; середовище пам'яті; схильність; навичка; вибір профресії; смартпідхід.

(C) Oleg Maltsev

Надійшла до редакції: 04.05.2020

Прийнята до друку: 27.05.2020

СХІД № 3 (167) травень-червень 2020 р. 